\title{
Apoptosis at the time of embryo implantation in mouse and rat
}

\author{
Serge Pampfer ${ }^{*, 1}$ and Isabelle Donnay ${ }^{2}$ \\ ${ }^{1}$ OBST 5330 Research Unit, Université Catholique de Louvain Medical School, \\ Brussels, Belgium \\ 2 VETE Research Unit, Université Catholique de Louvain Faculty of Sciences, \\ Louvain-la-Neuve, Belgium \\ * corresponding author: Serge Pampfer, OBST 5330, Université Catholique de \\ Louvain Medical School, 53 Avenue Mounier, 1200 Brussels, Belgium. \\ tel: 32-2-764 5425; fax: 32-2-764 5396; e-mail: pampfer@obst.ucl.ac.be
}

Received 7.12.98; revised 15.02.99; accepted 22.03.99

Edited by M. Piacentini

\begin{abstract}
The aim of this review is to summarize the information currently available regarding the occurrence of apoptosis in the developing embryo and in the receptive uterus during the peri-implantation period of gestation. Cell death is detected in the inner cell mass of late pre-implantation embryos as the result of an eliminative process that helps trim the embryonic cell lineages of surplus or dysfunctional stem cells. Cell death is also detected in the epiblastic core of early postimplantation embryos, where the process is implicated in the formation of the pro-amniotic cavity. On the maternal side, uterine epithelial cells situated around the attachment site undergo cell death during the initial phase of implantation in order to facilitate embryo anchorage and access to maternal blood supply. Uterine stromal cells closest to the implantation chamber first transform into decidual cells and then commit suicide to make room for the rapidly growing embryo. Although apoptosis is well recognized as a crucial determinant of successful peri-implantation development, our understanding of the cellular and molecular mechanisms regulating this process clearly lags behind the comprehension of cell death control in other systems.
\end{abstract}

Keywords: Blastocyst; epithelium; decidua; trophoblast

Abbreviations: ICM: inner cell mass; TE: trophectoderm; TGF: transforming growth factor; TNF: tumor necrosis factor

\section{Introduction}

Based upon observations first reported in the middle of the 19 th century ${ }^{1}$ and substantially expanded in more recent years, ${ }^{2}$ the term 'programmed cell death' has been proposed to indicate the elimination of specific cells at pre-determined locations and times. The descriptive collection of morphological and biochemical features displayed by cells undergoing elimination was termed 'apoptosis' ${ }^{3}$ and the predictability of this process was initially viewed as resulting from the operation of an autonomous cell suicide machinery under the control of an intrinsic biological clock. Although the targeted cells appear to self-destruct from within, it is now increasingly recognized that the cascade of intra-cellular events that lead to cell elimination rarely occurs in a strictly endogenous context. ${ }^{4}$ In most situations indeed, cell suicide is open to modulation by a variety of extra-cellular determinants such as the exposure to death-activating signals or the withdrawal of survival-promoting factors.

Numerous review articles have been published on the occurrence of cell death during both early and late organogenesis 5,6 and on its role in the regulation of ovarian and endometrial regression. ${ }^{7-9}$ The present review article is an attempt to summarize our current knowledge of the incidence of cell death in the embryo and in the uterus during a less intensively studied phase of the reproductive process: the peri-implantation period. The first part of the paper will summarize the general sequence of events unfolding in laboratory mice and rats during the periimplantation phase of gestation. The second part will describe the available evidence indicating that cell suicide occurs in peri-implantation embryos and how this process might be regulated. The third part will review the studies describing the occurrence of cell death in the uterine region that surrounds the implanted embryo and what is known about the control of this process. In many instances, short descriptions of how cell death was identified or quantitated are given in order to emphasize the extreme variability of the criteria that were used to characterize this cellular event.

\section{An overview of the peri-implantation period of development in mice and rats}

The earliest morphogenetic event to occur during the initial phase of embryogenesis is the compaction of the cleaving blastomeres into a coherent mass of cells (morula stage). This morphological step is then followed by the formation of a central cavity (blastocoele) within the embryo and the partitioning of the blastomeres between two distinct cell lineages: the inner cell mass (ICM or embryoblast) and the trophectoderm (TE). Cells in the ICM soon begin to differentiate into an outer layer of primitive endoderm (hypoblast) surrounding an inner core of primitive ectoderm (epiblast). TE cells directly adjacent to the ICM form the polar TE while those lining the blastocoele produce the mural TE. As the blastocoelic cavity continues to expand within the blastocyst, the embryo itself hatches from the zona pellucida, becomes positioned near the end of an antimesometrial uterine indentation and begins to adhere by its abembryonic pole to the receptive uterine lining (Figure 1). Orientation of the blastocyst during initial attachment to the mouse and rat uterine wall has the ICM facing the mesometrial aspect of the uterus. While the mural TE cells initiates its differentiation into 
primary giant trophoblasts, ICM cells and polar TE cells combine into a cylindrical structure (egg cylinder) containing a core of embryonic ectoderm and extra-embryonic ectoderm that is surrounded by an outer layer of primitive endoderm. This latter population of peripheral cells then differentiate into the extra-embryonic parietal and visceral endoderms which will contribute structural elements to the yolk sac later in embryogenesis. Polar TE cells also develop into ectoplacental cone cells and secondary giant trophoblasts. Shortly after implantation is completed, a pro-amniotic cavity develops within the epiblast. Gastrulation begins soon thereafter with the appearance of the primitive streak which forms in a region of the epiblast adjacent to the embryonic/ extra-embryonic junction.

At the same time as these embryological events occur, the uterine lumen around the implanted embryo progressively closes and an intense edema soon develops in the endometrial zone surrounding the site of nidation. Implantation triggers a sequence of organizational and functional changes in the resident fibroblast-like cells of the stromal area that is directly adjacent to each embryo. The subepithelial region, which is being transformed into a narrow avascular layer known as the primary decidua, is then rapidly penetrated by secondary giant trophoblasts. These cells invade the uterine tissue until they reach maternal blood vessels in the antimesometrial region and create a primitive irrigation system in the vicinity of the embryo. Concomitantly, important modifications occur in the range of inter-cellular junctions established between decidual cells as well as in the composition and structure of the extracellular matrix, translating into a profound re-modeling of the peri-implantation zone. The primary decidua becomes progressively surrounded by a secondary decidual layer which proceeds gradually from the antimesometrial center to the mesometrial pole. As the process of decidualization continues, a cross-section view through a typical implantation site reveals four distinct zones which comprise, along a bottom-up axis, a decidual crypt, an antimesometrial chamber containing the embryo, a mesometrial chamber (the anticipated site of chorio-allantoic placenta formation) and a remnant of the uterine lumen. The decidualized region located on the mesometrial side of the uterus, which is called the decidua basalis, will persist throughout gestation.

\section{Cell death in the peri-implantation embryo} Cell death at the blastocyst stage

The first indication that cell death occurs in the mouse blastocyst as it prepares for its implantation was based on the observation of numerous basophilic bodies predominantly located in ICM cells. ${ }^{10}$ At the time, these initial observations were incorrectly interpreted as signaling the degeneration of invasive ICM cells migrating into the uterine epithelium ${ }^{11}$ or, inversely, the phagocytosis of uterine epithelial cells by trophoblasts. ${ }^{12}$ Based on the detection of large vesicles filled with lysosomal acid phosphatase, subsequent studies confirmed the degeneration of a limited number of cells in the ICM of mouse blastocysts. ${ }^{13}$ More sophisticated experiments based on electron microscopy revealed that these ICM dead cells were characterized by a combination of nuclear pyknosis (condensation of the chromatin and the loss of nuclear membrane) and cytoplasmic changes (swelling of the endoplasmic reticulum). ${ }^{14}$ Other studies, based on the reconstruction of serially sectioned mouse blastocysts, corroborated the confinement of dead cells to the ICM and extended beyond the previous findings by showing that the occurrence of cell death in the ICM lineage was a transient event (cells were classified as dead when their nucleus was either condensed or divided in several dense chromatin bodies). ${ }^{15}$ Maximal cell death incidence was found to coincide with the initiation of the differentiation process into primitive ectoderm and endoderm layers. That observation was confirmed in another study in which mouse embryos were collected at intervals during the blastocyst period. Dead cells
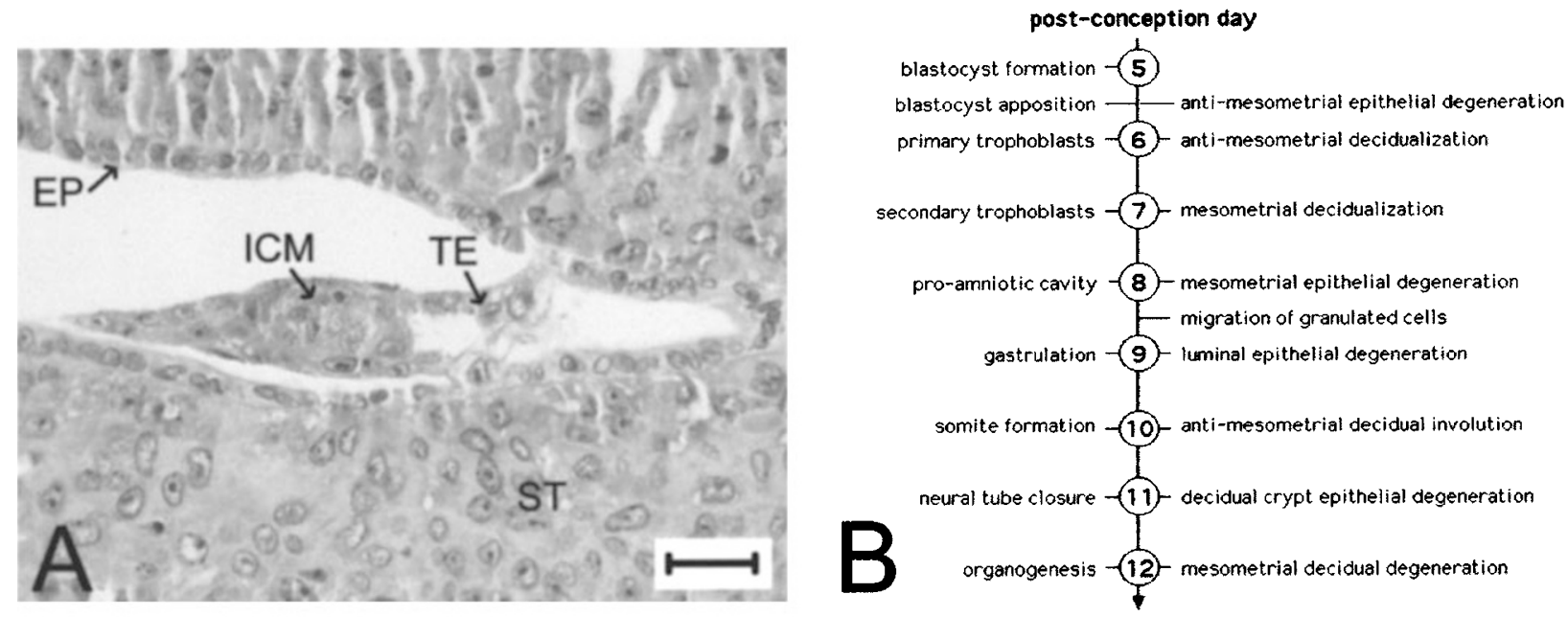

Figure 1 Implantation of the rat blastocyst. (A) Histological section showing a blastocyst engaged in the process of adhesion to the receptive uterus. ICM=inner cell mass, TE=trophectoderm, EP=uterine epithelium, $\mathrm{ST}=$ decidualizing uterine stroma (scale bar $=30 \mu \mathrm{m}$ ). (B) Timetable of the implantation and decidualization process (scheduled in days after conception) 
(about $8 \%$ at peak level) in that report were those with a nucleus disintegrated into a cluster of highly fluorescent fragments and a plasma membrane still able to exclude a living cell impermeant dye (propidium iodide). ${ }^{16}$

The realization that limited cell suicide occurs during early embryo growth takes on broader significance with the observation that its frequency can increase under certain conditions. There is now growing evidence that such a situation may exist in vivo when the uterine environment is altered by maternal diabetes. Using nuclear fragmentation within intact cell membranes as a marker, a fourfold increase has been detected in the incidence of cell death in the ICM lineage of blastocysts recovered from diabetic rats. ${ }^{17,18}$ Blastocysts from diabetic rats ${ }^{19}$ and mice ${ }^{20}$ also contain a higher proportion of cells with nuclear chromatin degradation, as revealed by TUNEL staining. Excess cell death in these blastocysts was corrected by achieving maternal normoglycemia through insulin administration. ${ }^{20,21}$ Maintaining embryos under standard culture conditions can also produce a situation conducive to excessive cell death in blastocysts. Based on the scoring of cells whose nucleus exhibited intense fluorescence staining due to chromatin condensation, the incidence of cell death was found to be twice as high in mouse blastocysts fertilized and cultured in vitro than in blastocysts conceived in vivo. ${ }^{22}$ Many (but not all) of the condensed nuclei contained highly degraded chromatin material, as revealed by TUNEL staining. In other experiments, the incidence of cell death (presence of a fragmented nucleus within a propidium iodide-repulsive cell membrane or positive TUNEL staining) was threefold higher in mouse blastocysts cultured from the two-cell stage onwards compared to blastocysts grown in vivo. ${ }^{23}$ This increase occurred predominantly in the cells of the ICM lineage. Supplementation of the incubation medium with TGF- $\alpha$ resulted in a partial prevention of cell death, suggesting in combination with the detection of TGF- $\alpha$ mRNA and protein synthesis in the uterus at the time of implantation $^{24,25}$ as well as in the blastocysts themselves $^{26,27}$ that TGF- $\alpha$ may be a survival factor in utero. Further support for that proposal was recently provided by observations that TGF- $\alpha$-null blastocysts featured a twofold higher incidence of cell death in their ICM compared with wild-type blastocysts. ${ }^{28}$ If some of the growth factors and cytokines secreted by the cells lining the reproductive tract and/or by the growing embryos act as survival factors, other effectors of this type should be expected to exert the opposite effect. Data are available suggesting that TNF- $\alpha$ may function as one of these negative regulators. TNF- $\alpha$ synthesis has been confirmed at both $\mathrm{mRNA}^{29}$ and protein $^{30}$ levels in rat uterine epithelial cells at the time of implantation and rat blastocysts express one of the two TNF- $\alpha$ receptor isoforms. ${ }^{31}$ Maintaining rat blastocysts in a culture medium supplemented with TNF- $\alpha$ increased the incidence of TUNEL-positive nuclei, but not the frequency of nuclear fragmentation, in the ICM cells of these embryos compared to control embryos. ${ }^{19}$ The intriguing observation that chromatin degradation may be induced by TNF- $\alpha$ without triggering a concomitant increase in nuclear fragmentation was confirmed in mouse embryonic stem cells exposed to the same cytokine, ${ }^{32}$ suggesting that these two nuclear events can be activated independently in embryonic cells. In mouse blastocysts, exposure to TNF- $\alpha$ caused a substantial loss of cells in the ICM lineage ${ }^{33}$ and increased the rate of fetal resorption after transfer into recipient mice. ${ }^{34}$ Collectively, the TGF- $\alpha$ and TNF- $\alpha$ data thus clearly suggest that external signals can influence the proportion of cells that are eliminated from the ICM lineage. An interesting question is whether intra-cellular death effectors are constitutively expressed in blastocysts. Recent experiments have demonstrated that following exposure to a combination of protein kinase inhibitor staurosporine and protein synthesis inhibitor cycloheximide, a high proportion of mouse blastocyst cells contained a fragmented nucleus surrounded by an impermeable cell membrane ${ }^{35}$ or a TUNEL-positive nucleus. ${ }^{35}$ These results suggest that rendering the blastocyst irresponsive to extra-cellular and intra-cellular survival signals by means of biochemical inhibitors may unlock constitutively expressed (but normally restrained) death effectors. More exploratory work remains to be done, however, before conclusions about this aspect of cell death regulation are considered secure.

The apparent randomness of cell suicide within the ICM lineage makes it unlikely that this eliminative process serves a morphogenetic function. The alternative hypothesis is that cell death allows for the deletion of a minority of cells with redundant or deleterious potential. This concept is based on past studies that involved two murine embryonal carcinoma cell lines with distinct differentiation potential. Initial experiments indicated that injecting $\mathrm{ECa}$ 247 cells into the cavity of giant trophoblast vesicles (thus exposing these cells to blastocoele-like fluid) resulted in their rapid killing whereas similarly injected $\mathrm{P} 19$ cells were found to survive and proliferate. ${ }^{36}$ Because ECa 247 cells have a trophectoderm potential whereas P19 cells have an embryonic potential, the differential killing effect was interpreted as an indication that ICM cells with the potential to form TE derivatives are deleted from late blastocysts. Subsequent investigations suggested that free radicals produced by the oxidation of polyamines may function as mediators of the toxic activity accumulated in the blastocoele-like fluid $^{37}$ and that a deficiency in glutathione-dependent resistance to peroxides may mark ICM cells with trophectodermal potential for elimination. ${ }^{38}$ Unfortunately, the highly modelized conditions used in these experiments did not allow for a conclusive statement about the purpose of cell suicide in blastocysts. Preliminary data obtained in our laboratory seem to confirm, however, that oxidative stress may be implicated in this process since exposing rat blastocysts to the anti-oxidant $\mathrm{N}$ acetylcysteine in vitro elicited a dose-dependent reduction in the frequency of cell death (nuclear fragmentation within an intact plasma membrane) in the ICM lineage (Figure 2).

\section{Cell death in the early post-implantation embryo}

At the time the blastocyst engages into the process of implantation, cells in the ICM begin to differentiate into a central core of primitive ectoderm separated from the blastocoele cavity by a layer of primitive endoderm. A central 

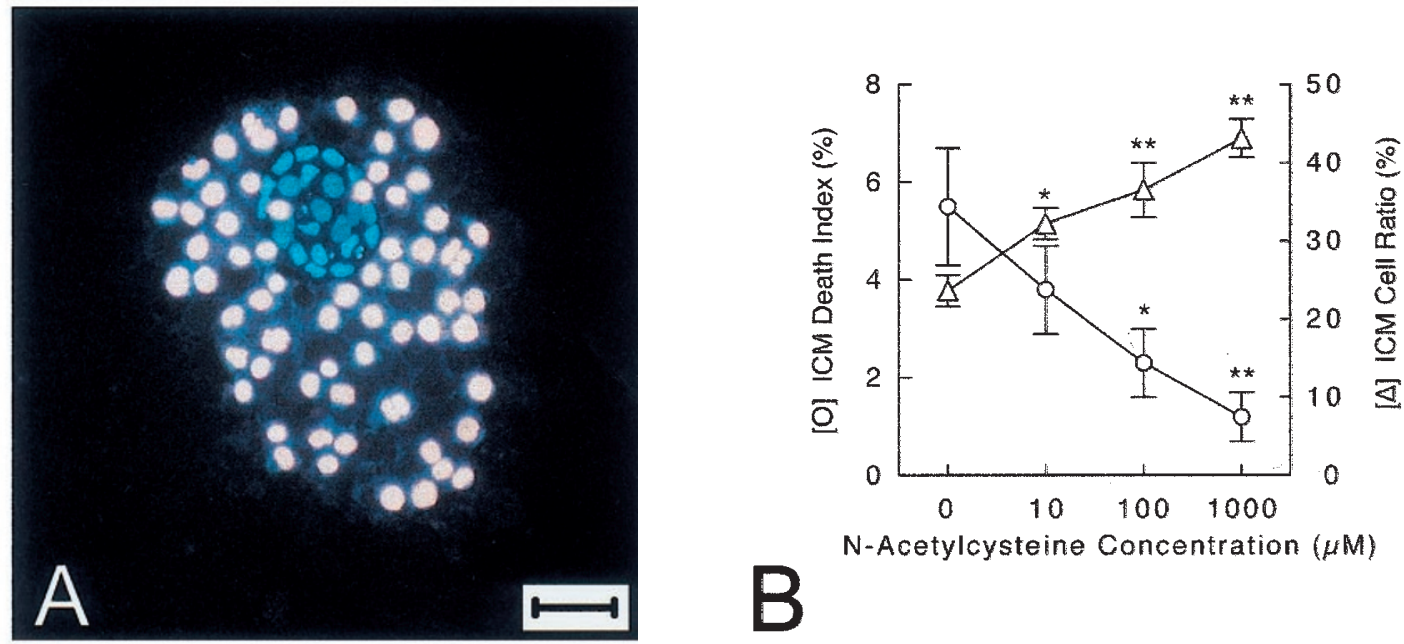

Figure 2 Influence of the antioxidant $\mathrm{N}$-acetylcysteine on the growth of the inner cell mass in rat blastocysts. (A) Use of a differential staining technique that allows for the separate counting of cell numbers in the ICM and TE lineages in individual blastocysts (as described in 17). Nuclei contained in ICM cells appeared blue and those in TE cells were stained red under epifluorescence (scale bar=20 $\mu \mathrm{m}$ ). (B) Effect of N-acetylcysteine on the relative contribution of ICM cells to the total number of cells per blastocyst (ICM Cell Ratio (\%)) and on the proportion of ICM nuclei that appeared fragmented into small, irregular and highly fluorescent particles (ICM Death Index (\%)) after application of the differential ICM/TE technique. Between 15 and 20 blastocysts were counted per group. $\left({ }^{*}\right)$ and $\left({ }^{* *}\right)$ indicate significant difference at $\mathrm{P} \leqslant 0.05$ and 0.01 respectively from the corresponding control value without $\mathrm{N}$-acetylcysteine. Blastocysts were flushed from normal rats and incubated for $48 \mathrm{~h}$ in the presence of increasing concentrations of $\mathrm{N}$-acetylcysteine before examination. Cell proliferation in the trophectoderm lineage was not affected by the treatment

lumen (the pro-amniotic cavity) then appears in the ectodermic core. The resulting embryonic configuration is an empty structure surrounded by a single layer of ectoderm, itself covered by a single layer of endoderm. Examination of histological sections of both mouse and rat implanting blastocysts revealed the presence of dead cells (nuclear condensation and irregular cell shape) in the nascent cavity, ${ }^{39}$ suggesting that pro-amniotic cavitation proceeds by cell deletion within the ectoderm. Dead cells or cell fragments with pyknotic nuclei were also observed in the cavity of embryoid bodies formed within aggregates of embryonal carcinoma cells. ${ }^{40}$ Furthermore, internucleosomal DNA fragmentation was detected by electrophoretic analysis in cavitating embryoid bodies. Additional experiments involving the construction of chimeric structures by combining different embryonal carcinoma cell lines and primitive endoderm cell lines demonstrated that pro-amniotic cavitation results from the interplay of conflicting signals. ${ }^{39}$ According to the data, a first signal (originating from the visceral endoderm) induces the elimination of the innermost ectoderm cells whereas a second signal (depending on interactions with the basement membrane between the ectoderm and endoderm layers) prevents the deletion of the outermost ectoderm cells. Thus, in contrast to the situation described in the ICM of preimplantation blastocysts, occurrence of cell death in the epiblast of the implanting embryo is clearly associated with a defined morphogenetic event. The nature of the signals controlling the formation of the pro-amniotic cavity remains to be identified. Interestingly, evidence of limited random cell death (cytoplasmic condensation, nuclear pyknosis and TUNEL staining) is again described slightly later in the primitive embryonic ectoderm layer of the pre-gastrulating embryo $^{41,42}$ and in the peripheral cells of the ecto-placental cone. ${ }^{2}$ This scattered distribution of dead cells across the epiblast shifts progressively towards the distal anterior region as the embryo engages into the process of gastrulation. In contrast, cell deletion is only very occasionally detected in the nascent mesoderm ${ }^{41,43}$ and no indication of cell death at all is found in the axial visceral endoderm at the same developmental stage. ${ }^{42,44}$

\section{Molecular mechanisms of cell death in the embryo}

The assumption that cell elimination in implanting embryos results from the activation of a genetically controlled program implies that the expression of genes associated with the cell suicide pathway should be detected at that developmental stage. Although more than 15 different members of the $\mathrm{Bcl}-2$ protein family have been identified so far, ${ }^{45}$ our current knowledge of their expression in mouse blastocysts is limited to the detection of transcripts encoding the anti-apoptotic effector $\mathrm{Bcl}-2$ and the pro-apoptotic effector Bax. ${ }^{35}$ Transcription of the Bcl-2 gene is also detected at both mRNA and protein levels in rat blastocysts (Figure 3). Compared with control embryos, increased Bax mRNA and protein levels have been measured in blastocysts from diabetic mice or following incubation in high glucose, suggesting the sensitivity of Bax expression to extra-embryonic influences. ${ }^{20}$ Little is known about the embryonic expression of the multiple members of the caspase family of cysteine proteases that are responsible for initiating and operating the disassembly of structural components in dying cells. ${ }^{46}$ Screening mouse 


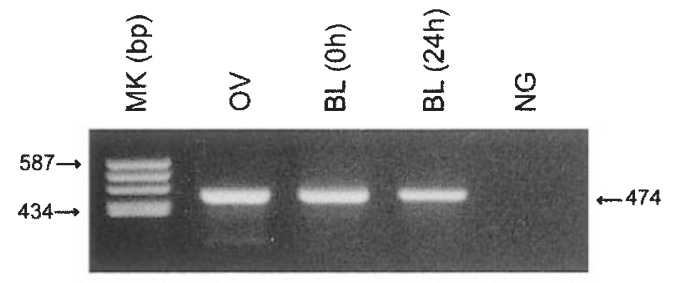

A
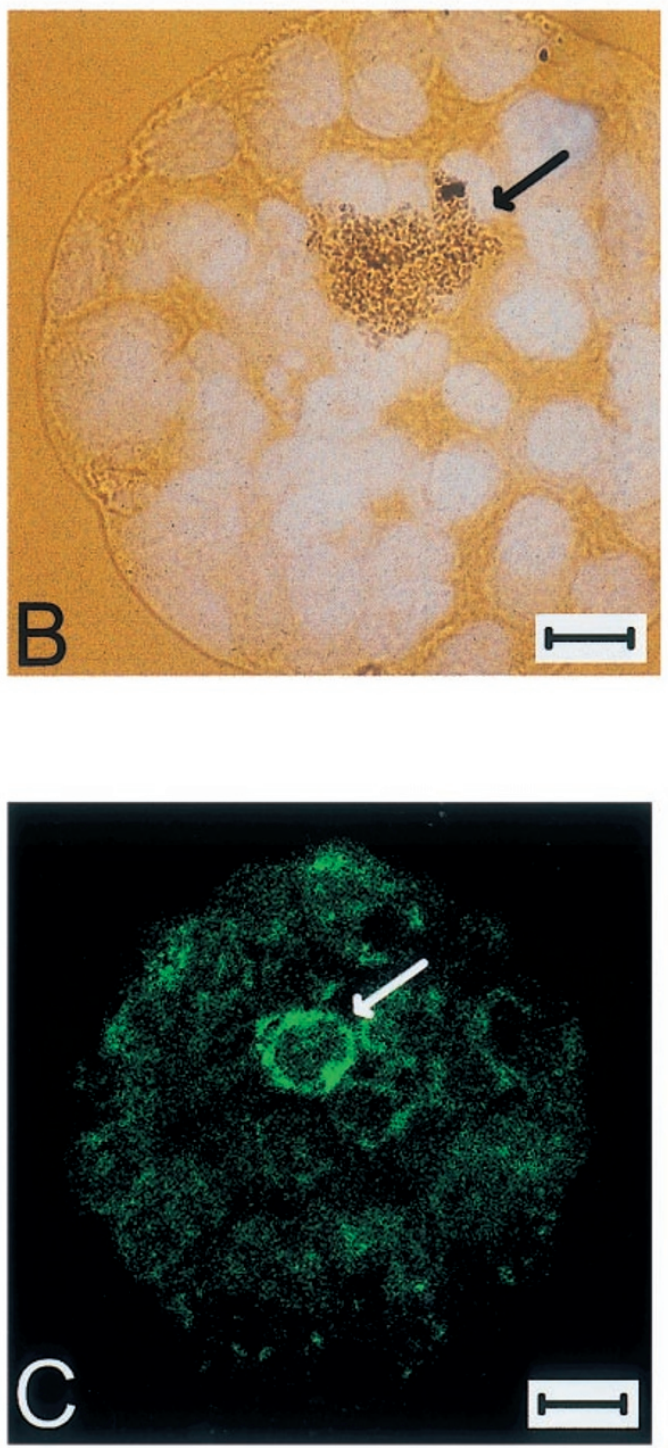

Figure 3 Expression of $\mathrm{Bcl}-2$ in rat blastocysts. (A) Total RNA was extracted from freshly collected blastocysts $(B L(0 h))$ and from 24-h cultured blastocysts $(\mathrm{BI}(24 \mathrm{~h})$ ) and retro-transcribed with polydT primers and MMLV reverse transcriptase before thermal cycling amplification with two $\mathrm{Bcl}-2$ specific primers and Taq polymerase. An amplicon was detected at the expected DNA size (bp) by gel electrophoresis. Positive control reaction was blastocysts for caspase transcripts has revealed the expression of caspase-2 and caspase-3, but not caspase$1{ }^{35}$ Mouse blastocysts also contain high levels of transcripts for the growth arrest-specific gene 6 (gas6). ${ }^{47}$ Gas 6 transcription is stimulated in F9 embryonal carcinoma cells upon their culture in amino acid-deficient medium ${ }^{48}$ and previous studies have shown that gas 6 proteins operate as divalent ligand between phosphatidylserine residues and cells expressing gas6-specific receptors. ${ }^{49}$ Because the translocation of internal phosphatidylserine residues to the cellular surface functions as a tag that signals apoptotic cells for removal by scavenger cells, ${ }^{50}$ it is possible that gas 6 synthesis may be associated with the elimination of dead cells in blastocysts. In that respect, gas 6 expression may be correlated with the detection of transcripts encoding clusterin, another scavenger of cellular debris, in rat blastocysts. ${ }^{19}$ Blastocysts recovered from diabetic rats or cultured in high concentrations of glucose were found to contain higher levels of clusterin transcripts than control embryos, suggesting that more embryonic cells require elimination during the exposure to high glucose. In contrast to clusterin receptors, whose expression is restricted to the peripheral cells of the TE in mouse and rat embryos, ${ }^{51}$ the presence of gas6-specific receptors has not been documented at the blastocyst stage. Another interesting gene whose transcription has been detected in mouse blastocysts ${ }^{47}$ and in amino acid-deprived F9 embryonal carcinoma cells ${ }^{48}$ is the growth arrest and DNA damage-inducible gene 153 (gadd153). Previous experiments have shown that the gadd153 gene product, which is up-regulated by peroxide-mediated oxidative stress and by ceramide, ${ }^{52}$ acts along a still unknown signaling cascade that leads to cell death. ${ }^{53}$

An indirect way to determine the relevance of apoptosisassociated genes during the peri-implantation phase is to test whether their deletion impairs early embryo development. An overview of the knockout mice already reported for four members of the Bcl-2 family and six different caspases reveals that none of these effectors (at least on an individual basis) is required for normal peri-implantation development (Table 1). An explanation for this absence of

performed on rat ovary cDNA (OV). Negative control reaction was carried out without cDNA input (NG). (B) In situ hybridization was performed on a blastocyst using a biotinylated antisense probe specific for rat Bcl-2 mRNA. Revelation of the hybridization signal was carried out by means of a peroxidase-dependent color reaction. Counter-stain of the cell nuclei was performed with a DNA fluorochrome. Bcl-2 mRNA expression appeared as a cluster of dark dots in the cytoplasm of positive cells (arrow) (scale bar $=10 \mu \mathrm{m}$ ). Analysis of 30 blastocysts showed that only a very limited number of cells were strongly positive $(1.4 \pm 0.3 \%$ of total cell number per blastocyst). Repeated control reactions with the corresponding sense probe produced no labeling (data not shown). (C) Immunocytochemical analysis was performed on a blastocyst using a primary rabbit polyclonal antibody raised against the rat $\mathrm{Bcl}-2$ protein and a secondary goat anti-rabbit IgG antibody coupled with fluorescein. Examination was performed by confocal laser microscopy (scale bar $=17 \mu \mathrm{m}$ ). Analysis of 14 blastocysts showed that almost all the TE and ICM cells were weakly stained for $\mathrm{Bcl}-2$ and that strong positive immunostaining (arrow) was restricted to a very limited number of cells, in support of the in situ hybridization observations. Control experiments without fluorescein-conjugated secondary antibody or with non-immune rabbit IgG substituted for the primary antibody demonstrated that both autofluorescence and non-specific background signals were negligible (data not shown) 
early phenotype is that the existence of multiple members in the $\mathrm{Bcl}-2$ and caspase families creates high redundancy in the cell death pathway(s) so that the loss of any one member would not impact significantly on the ability of the null embryos to reach the late organogenesis phase. Alternatively, the dependence of developmentally-relevant apoptotic pathways on effectors of the $\mathrm{Bcl}-2$ and caspase protein families may be transiently low or null in early embryonic cells. In keeping with the above observations, mouse embryos deficient in Apaf-1, an apoptotic mediator acting downstream of Bcl-2 and upstream of caspase- 9 and caspase-3, were found to develop normally up to pregnancy day $12 . .^{73,74}$ Apaf- 1 is expressed in normal mouse embryonic stem cells, suggesting that the Apaf- 1 gene may be already active at the blastocyst stage. Interestingly, Apaf-1-null embryonic stem cells are completely resistant to several pro-apoptotic stimuli in contrast to normal cells. ${ }^{74}$ Genomic deletion of various members of the NF- $\kappa \mathrm{B}$ family, whose role in the regulation of apoptosis is now well documented, ${ }^{75}$ also fail to induce embryolethality around the time of implantation (Table 1). Transcripts for NF- $\kappa \mathrm{B}$ were detected in mouse embryonic stem cells, however, suggesting that these effectors may be active in early embryonic regulation. ${ }^{76}$ The tumor suppressor $\mathrm{p} 53,{ }^{77}$ which can trigger apoptosis in certain cell types upon exposure to cellular stress, was also found to be dispensable for early embryonic development. ${ }^{78}$ Interestingly, undifferentiated embryonic stem cells produce high levels of p53 protein and their differentiation in vitro is accompanied by both a reduction in overall p53 content and a conformational change into a less functional isoform that render them more resistant to cell death induction. ${ }^{79}$ This correlation between undifferentiated cell status, high p53 expression and high sensitivity to cell killing was exemplified in a recent study showing that numerous malformed fetuses were generated from p53-null embryos when exposed to X-rays at the blastocyst stage. ${ }^{80}$ It is assumed that embryos deficient for p53 are more prone to abnormalities due to their inability to eliminate $\mathrm{X}$-raydamaged cells. Conversely, mouse embryos lacking the mouse-double-minute-2 (MDM2) gene whose protein is a negative regulator of $p 53^{81}$ were found to die shortly after implantation. ${ }^{82,83}$ Abnormally low numbers of cells were detected in the ectoderm layer of $\mathrm{MDM}^{-1-}$ egg cylinder embryos, probably because the lack of p53 down-regulation led to dominant cell arrest and/or cell death. No experiment was carried out, however, to visualize the occurrence of cell death in $\mathrm{MDM}^{-/-}$pre-gastrulating embryos.

Interestingly, the disruption of several genes whose functions are not directly related to apoptosis results in increased cell death in implanting blastocysts. Although it would be beyond the scope of this paper to review and comment on all these knock-outs, the following examples have been selected as particularly interesting. Mouse blastocysts lacking the gene coding for the extra-cellular matrix receptor integrin- $\beta 1$ were found to initiate the differentiation of the trophectoderm cells but were unable to form primitive endoderm derivatives at the blastocoelic surface of their inner cell mass. ${ }^{84,85}$ Those very few cells that manage to differentiate into endoderm at the periphery of the inner cell mass displayed signs of nuclear pyknosis. In keeping with these observations, extensive cell degeneration was found in cultures of integrin- $\beta 1^{-/-}$embryonic stem cells upon induction of differentiation in vitro. The second knock-out relates to mouse embryos made deficient for the hepatocyte nuclear factor-4 (HNF-4) gene. Early post-implantation embryos without HNF-4 were significantly delayed in the formation of the mesodermal derivatives between the embryonic ectoderm and endoderm layers of the cell cylinder. ${ }^{86}$ Cells containing a pyknotic nucleus or stained positive by the TUNEL technique were abundant in the embryonic ectoderm of HNF-4 null embryos, especially in the posterior region from which mesoderm arises during gastrulation. Nuclear pyknosis and TUNEL identification were also detected in the same distal portion of the embryonic ectoderm of embryos lacking the gene encoding huntingtin, the mouse homologue of the Huntington disease $(H D D)$ gene. $^{87}$ In both HNF-4 and HDD ${ }^{-1-}$ mutants, excessive cell death in the pre-gastrulating distal epiblast leads to a profound disruption of mesodermal formation and

Table 1 Consequences of cell death-associated gene ablation on embryonic development

\begin{tabular}{|c|c|c|c|c|}
\hline $\begin{array}{l}\text { Gene } \\
\text { family }\end{array}$ & Knock-out & Viability throughout development & Comments & References \\
\hline \multirow[t]{4}{*}{ Bcl-2 } & $\mathrm{Bcl}-2$ & Yes & Growth Retardation and Renal Hypoplasia & $55-57$ \\
\hline & Bax & Yes & Deficient Testicular and Ovarian Functions & 58 \\
\hline & $\mathrm{Bcl}-\mathrm{X}$ & Lethality around Day 12 & Excess Cell Death in Brain and Liver & 59 \\
\hline & Bcl-W & Yes & Testicular Degeneration & 60 \\
\hline \multirow[t]{6}{*}{ Caspase } & Caspase-1 & Yes & & 61,62 \\
\hline & Caspase-2 & Yes & Excess Cell Death in Motor Neurons & 63 \\
\hline & Caspase-3 & $\begin{array}{l}\text { Lethality around Day } 14 \\
\quad \text { (not all }-/- \text { embryos affected) }\end{array}$ & Brain Hyperplasia & 64 \\
\hline & Caspase-8 & Lethality around Day 13 & Impaired Heart Muscle Development & 65 \\
\hline & Caspase-9 & Lethality around Birth & Brain Hyperplasia & 66 \\
\hline & Caspase-11 & Yes & & 67 \\
\hline \multirow[t]{5}{*}{$\mathrm{NF}-\kappa \mathrm{B}$} & p50 & Yes & & 68 \\
\hline & p52 & Yes & Lymphoid Abnormalities & 69 \\
\hline & p65/RelA & Lethality around Day 15 & Liver Degeneration & 70 \\
\hline & RelB & Yes & Hematopoietic Abnormalities & 71 \\
\hline & $\mathrm{I} \kappa \mathrm{B} \alpha$ & Yes & Skin Defects & 72,73 \\
\hline
\end{tabular}


to rapid embryonic demise. Embryo degeneration is probably due to the failure of visceral endoderm and extra-embryonic mesoderm to join in the yolk sac and to provide nutritive support to the conceptus. In support of this hypothesis, normal pre-gastrulating embryos cultured in a medium with a reduced concentration of glucose showed markedly increased levels of cell death in the distal epiblastic region. ${ }^{42}$ Other interesting mutants were those generated by deleting the Ref-1 gene (whose corresponding protein is involved in the repair of apurinic/apyrimidic DNA damages), and the Rad51 gene (whose product participates in DNA recombinational repair). In both cases, excessive cell death was observed in the region of the presumptive amniotic cavity. ${ }^{88,89}$

\section{Cell death in the uterus}

\section{Cell death in the uterine epithelium}

The observation that luminal epithelial cells facing the mural trophoblasts appear to detach from their basal lamina during the phase of apposition has been reported a long time ago in the rat ${ }^{90}$ and in the mouse. ${ }^{91,92}$ The immediate consequence of this exfoliation process is that the trophoblasts come in direct contact with the residual basement membrane. The loss of the epithelial lining continues anti-mesometrically beneath the implantation site and then progressively extends mesometrically (Figure 1). Early descriptions based on electron microscopy have demonstrated that degenerating epithelial cells located along the lateral margins of the implantation sites round up and show moderate signs of alterations in their cytoplasmic organelles and nucleus. ${ }^{90}$ Cellular debris can be seen in the residual uterine lumen but most degenerated cells seem to be promptly engulfed and removed by trophoblasts. Additional observations based on a combination of light and electron microscopy have revealed a three-phase sequence in the anti-mesometrial area of the mouse uterus. ${ }^{93}$ First, a small number of individual epithelial cells begin to display signs of nuclear deterioration (chromatopyknosis) while viable epithelial cells containing dense acid phosphatase-rich lysosomal vacuoles appear next to these isolated degenerating cells. Degeneration then extends to the whole anti-mesometrial lining with most epithelial cells containing cytoplasmic bodies identified as autophagic vacuoles (autophagosomes). Swelling of endoplasmic reticulum and golgi vesicles, accumulation of chromatin along the nuclear margins and nuclear fragmentation are then observed when these cells reach an advanced stage of degeneration. ${ }^{93}$ Subsequent analysis of rat implantation sites confirmed the pattern of cellular shrinkage and chromatin alterations. ${ }^{94}$ Decidual cells adjacent to rat implantation chambers are also strongly positive for tissue transglutaminase, an enzyme catalyzing cross-linking reactions and whose activation is associated with apoptosis. ${ }^{95}$ Investigations in the mouse ${ }^{96}$ and in the rat ${ }^{97}$ confirmed the digestion of displaced epithelial cells by nearby trophoblasts. When histological sections through rat implantation sites are analyzed for acid phosphatase activity, however, highest levels of this marker of phagocytosis are found in decidual cells, ${ }^{95}$ suggesting that both trophoblast and decidual cell types are likely to participate in the elimination of dying cells from the regressing area. Trophoblast phagocytosis begins after the epithelial cells have undergone considerable degradation, suggesting that the breakdown of the epithelium is primarily the result of an internal autolytic mechanism. Epithelial cell elimination at the time of implantation is inhibited when pregnant mice are treated with actinomycin-D, an inhibitor of mRNA synthesis. ${ }^{98}$

As gestation advances, epithelial degeneration extends to the mesometrial side of the implantation chamber. In contrast to the degenerating epithelial cells in the antimesometrial region, the second wave of cell death is characterized by the sloughing of large sheets of adherent cells into the residual uterine lumen. Features such as the condensation of chromatin along the nuclear margins, the disruption of the nuclear and plasma membranes and the extensive destruction of most cytoplasmic organelles were observed in these mesometrial epithelial cells. ${ }^{99}$ Cell death in the mesometrial zone is initiated long before trophoblasts have expanded enough to reach that area of the implantation site. The final phase of epithelial cell death occurs in the lining of the remaining uterine lumen. This wave of cell death is coincident with the invasion of the surrounding sub-epithelial stroma by large numbers of bone marrow-derived granulated metrial gland cells which are then coming in contact with the basement membrane. Electron microscopic images indicate that peri-luminal degenerating cells were of two different types: with intact organelles (mitochondria) and chromatin condensation without nuclear fragmentation or with intact organelles and nuclear fragmentation. ${ }^{100}$

\section{Cell death in the uterine decidua}

In order to accommodate the expansion of the placental unit, a process of decidual involution soon follows the phase of stromal transformation that has produced the primary and secondary decidual zones. In the mouse, small decidual cells with pyknotic nuclei are first detected in the internal decidual layer close to the trophoblasts. ${ }^{101}$ Involution then progresses towards the periphery as the number of dying cells (nuclear chromatin aggregation and mitochondrial distension) increases. ${ }^{102}$ In the rat, cell degeneration also appears in the area immediately adjacent to the embryo ${ }^{103}$ and then spread throughout the anti-mesometrial zone. ${ }^{104}$ Examination by electron microscopy showed that deteriorating decidual cells were apparently engaged in autolytic activity and that their elimination was facilitated by trophoblastic phagocytosis. ${ }^{102}$ Instances of decidual cells being sloughed into the rat uterine lumen were also reported. ${ }^{104}$ Chromatin degradation in the anti-mesometrial region in pregnant mice was recently confirmed by TUNEL staining. ${ }^{105}$

\section{Mechanisms of cell death in the uterus}

The view that cell elimination in the luminal epithelium surrounding the implantation chamber and in the antimesometrial aspect of the mature decidua results from the activation of an intrinsic cellular pathway has been primarily established upon the fact that these two events also occur in 
the pseudo-pregnant uterus. It has long been recognized that, following adequate priming of the uterine tissues with ovarian steroids, a stromal reaction can be induced artificially in the absence of an embryo. ${ }^{106}$ This response elicits the formation of a deciduomata that is very similar (albeit not identical ${ }^{107}$ ) to true decidua. Extensive observations based on this model have confirmed that the pseudo-decidual reaction is followed by the involution of the anti-mesometrial region ${ }^{108}$ and preceded by the degradation of the luminal epithelium (in the rat, ${ }^{109}$ in the mouse ${ }^{110,111}$ ). Epithelial cells in the antimesometrial zone seem to detach progressively from the basal lamina and show clear signs of degradation (condensation and margination of the nuclear chromatin and dilation of the endoplasmic reticulum) which resemble those detected during normal implantation. ${ }^{111}$ Recent studies based on the visualization of nucleosomal DNA fragmentation support this concept. ${ }^{112} A$ second line of evidence pointing towards the existence of an innate cell death program activated around the implantation site in that the removal of the epithelial cells bordering the mesometrial region is induced before physical interactions are established with the embryonic trophoblasts. ${ }^{99}$

The notion that uterine cell death represents the terminal step of an autonomous cell differentiation process associated with decidualization does not preclude that interactions with certain cellular components of the implantation chamber may be required. Although trophoblasts are not directly cytotoxic on epithelial and decidual cells, their capacity to engulf and phagocyte cellular debris in the peri-implantation area has been demonstrated. Moreover, trophoblast processes have been shown to penetrate between uterine epithelial cells and to extend along the basal lamina, ${ }^{113-115}$ an activity contributing to the dislodgement of the epithelium. Interestingly, sub-epithelial decidual cells seem also capable of sending processes through the basal lamina ${ }^{116}$ and migrating granulated cells have been shown to displace epithelial cells in the mesometrial extremity of the implantation chamber. ${ }^{100}$ Since the retention of interactions with the underlying basement membrane is crucial for the survival of epithelial cells, ${ }^{117}$ physical lifting of this cell layer by trophoblasts and other uterine cell types may be directly implicated in the induction of cell death in the epithelial layer.

Production of urokinase-type plasminogen activator ${ }^{118}$ and metalloproteinase $-9^{119}$ has been detected in mouse primary giant trophoblasts at the onset of implantation as well as in ectoplacental cone cells later in development. Analysis of the proteolytic products of trophoblasts from mouse blastocysts demonstrated that both urokinase-type plasminogen ${ }^{120}$ and metalloproteinase- $9^{121}$ activities can be modulated by exposing the embryos to various growth factors or extra-cellular matrix components. Recent experiments based on the co-culture of uterine epithelial cells with mouse blastocysts suggest that spreading trophoblasts are able to induce the detachment of the epithelial layer, probably by causing the degradation of the underlying matrix. ${ }^{122}$ Examination of primary decidual tissues, on the other hand, showed that invading trophoblasts are surrounded by maternal cells expressing high levels of plasminogen activator inhibitor $-1^{123}$ and tissue inhibitor of metalloproteinase-3. ${ }^{105}$ Interestingly, stromal cells in deciduomata were also found to express these two inhibitors despite the absence of invading trophoblasts. In addition, it is not excluded that decidual cells may participate in the dramatic alterations of the extra-cellular matrix since metalloproteinase activity is detected in mouse deciduomata. ${ }^{105}$ Other observations indicate that the wave of apoptosis that extends throughout the mature decidua is preceded by a marked declined in the production of the tissue inhibitor of metalloproteinase-3 by the targeted cells. ${ }^{105}$ It is therefore tempting to speculate that decidual cell death may also occur as a consequence of extracellular matrix deprivation. The extreme scarcity of collagenous material in the degenerating decidua capsularis indeed contrasts with the abundant extra-cellular matrix accumulated in the outermost layer of undifferentiated stromal cells. ${ }^{104}$ In accord with the above findings, immunocytochemical analysis of cathepsin-D, an endopeptidase involved in intra-cellular protein degradation, showed that expression of this enzyme peaks at a time coincident with the highest level of epithelial degeneration. ${ }^{112}$ Later in the implantation process, increased expression of cathepsin-D parallels the induction in DNA degradation in regressing decidual cells. Other cysteine proteinases, such as cathepsin-B, also increase in decidual tissues at the start of the regressive process. ${ }^{124}$ In addition, the scavenger of tissue debris clusterin has been found to be expressed at both mRNA and protein levels in luminal epithelial cells somewhat distal to the locations where mouse blastocysts are implanting ${ }^{125}$ as well as in early decidualized stromal cells. ${ }^{126}$ In these uterine cell populations, clusterin synthesis was often associated with nuclear pyknosis. ${ }^{127}$ Cell deletion in the uterine epithelium has also been correlated with alterations in cell-to-cell contacts. Expression of the adhesion molecule E-cadherin, for instance, has been described around implantation sites in pregnant mice ${ }^{128}$ and more precisely at the interface between epithelial cells and trophectoderm cells during primary attachment. ${ }^{129}$ Analysis of E-cadherin expression in uterine sections collected at different intervals throughout the implantation period has shown a progressive decrease in the basal and lateral E-cadherin staining pattern in epithelial cells. ${ }^{130}$

Considering the role played by steroid hormones (or rather the withdrawal thereof) in the modulation of cell death in many cell systems, ${ }^{131}$ it is surprising that so little attention has been devoted so far to the study of the implication of hormonal signals in the induction of epithelial and decidual regression. ${ }^{132}$ Implantation and decidualization only succeed when pre-ovulatory estrogen, luteal progesterone and nidatory estradiol have adequately sensitized the uterine tissues. In ovariectomized mice, continuous treatment with progesterone has been found to reduce the amplitude of uterine epithelial cell death following the cessation of estradiol treatment. ${ }^{133}$ In cultures of a rat uterine epithelial cell line, the addition of progesterone prevented cell death (characterized by electron microscopy, DNA laddering gel analysis and TUNEL staining) upon serum starvation. ${ }^{134}$ In a seemingly conflicting finding, however, progesterone was found to stimulate the synthesis of the lysosomal proteinase 
cathepsin-D in the uterine epithelial cell layer of ovariectomized mice. ${ }^{135}$ In vivo, circulating concentrations of progesterone are maintained at high levels during the implantation period in pregnant mice ${ }^{136}$ and rats. ${ }^{137}$ Levels of progesterone receptor mRNA and protein expression remain also high in uterine tissues, ${ }^{112}$ indicating that if ovarian hormones are involved in the regulation of uterine cell death, they must operate at a more subtil level. One hypothesis that has been recently explored is that, in the presence of invariant levels of ovarian hormones and total progesterone receptor content, decidual regression may be associated with changes in the relative composition of the progesterone receptor isoforms expressed in the reproductive tissues. ${ }^{138}$ In the mouse regressing decidua, the inactive receptor isoform- $C$ is the dominant progesterone receptor variant detected in the stroma. ${ }^{139}$ Whether a similar change in hormone receptor expression occurs in the epithelial layer surrounding the implantation site is not known.

Although ovarian hormones are the key regulatory elements in the preparation of the reproductive tract for implantation, it is now widely accepted that the co-operation of numerous paracrine and juxtacrine effectors conditions the success of this process. Growth factors and cytokines produced and acting locally are among those crucial mediators. ${ }^{140}$ In this context, it is interesting to note that TGF- $\beta 1$ and/or TGF- $\beta 2$ have been postulated as capable of inducing cell death in regressing decidual cells. Expression of both TGF- $\beta 1^{141}$ and TGF- $\beta 2^{142,143}$ has been detected in the decidual region of the pregnant mouse, mainly in the mesometrial area, before the initiation of decidual involu- tion. Transcription of the TGF- $\beta 2$ gene has also been found in deciduomata of pseudo-pregnant mice. ${ }^{143}$ During decidual regression, detection of TGF- $\beta 2$ transcripts appears to be restricted to the decidua basalis ${ }^{144}$ and the production of $\alpha 2$-macroglobulin, a compound capable of neutralizing the biological activity of TGF- $\beta 2$, is also limited to the mesometrial region of the decidua. ${ }^{145}$ The lethal effect of TGF- $\beta 2$ has been demonstrated in primary cultures of rat decidualized stromal cells which showed an increase in the incidence of cell death (internucleosomal DNA fragmentation) when exposed to the growth factor. ${ }^{146}$ Other experiments suggest that uterine epithelial cells may be another target for the pro-apoptotic activity of TGF- $\beta 1$. Administration of TGF- $\beta 1$ into the uterine stroma of estradiol-sustained ovariectomized mice resulted in an increased incidence of cell death in the adjacent epithelial layer (condensation of chromatin and cytoplasm materials, positive TUNEL staining) ${ }^{147}$ and addition of TGF- $\beta 1$ to primary cultures of mouse epithelial cells triggered a similar effect. ${ }^{122}$ Interestingly, the interruption of estradiol injection to ovariectomized mice was found to be followed by an increase in the expression level of TGF- $\beta$ type II receptors in the cells of the uterine epithelium, suggesting that fluctuations in the hormonal environment may sensitize target cells to the influence of TGF- $\beta$ effectors. ${ }^{147}$

Another local agent that may be involved in uterine epithelial and decidual regression is the cytokine TNF- $\alpha$. Type I receptors for TNF- $\alpha$ are detected at the mRNA level in the uterine epithelium as well as in the distal stroma and their transcription is up-regulated by steroid hormones,
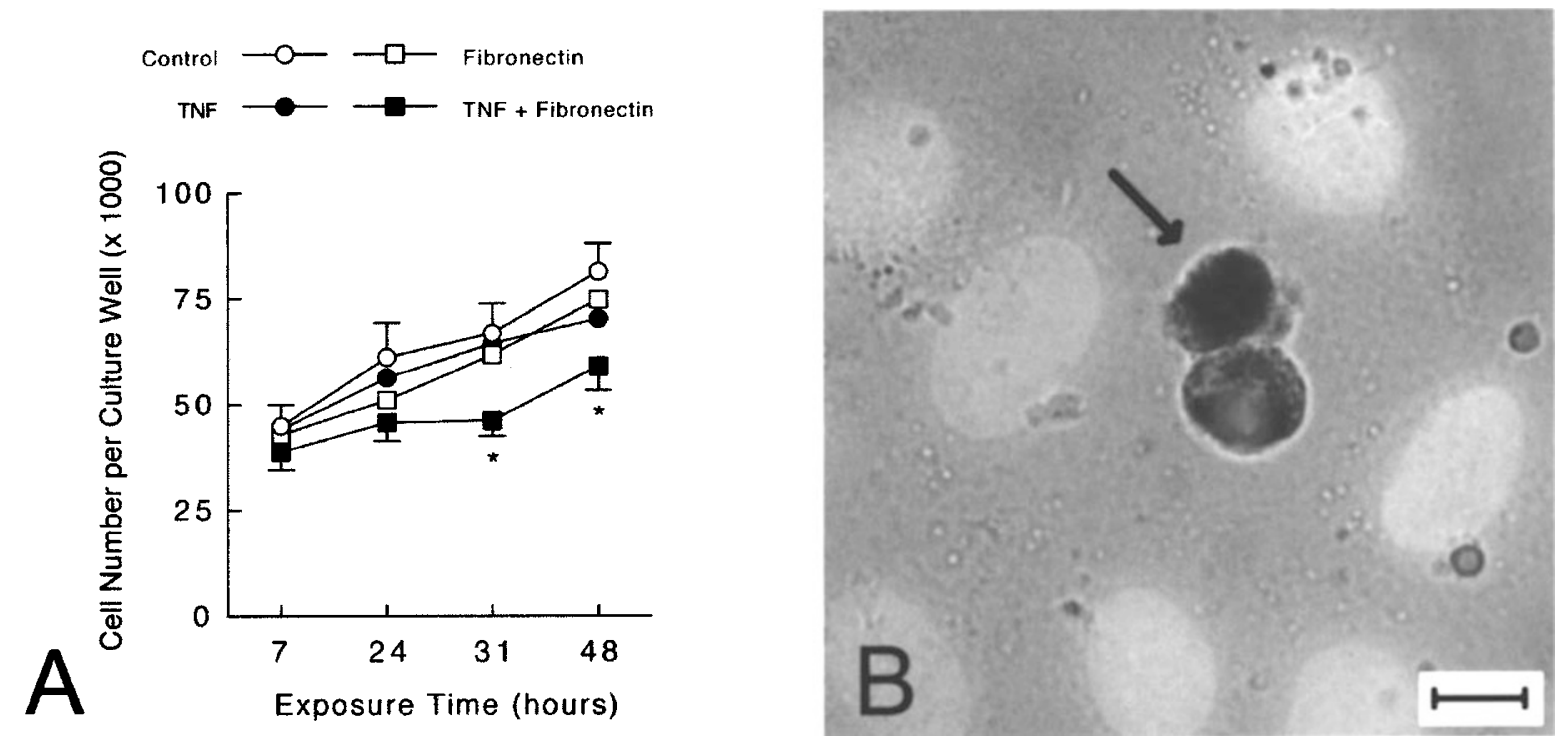

Figure 4 Impact of TNF- $\alpha$ on the survival of mouse uterine epithelial cells in vitro. (A) semi-confluence cultures of the uterine epithelial WEG-1 cell line were exposed to $5 \mathrm{ng} / \mathrm{ml}$ of mouse recombinant TNF- $\alpha$ and analysed at intervals for the number of trypan blue-negative (viable) cells over a total period of $48 \mathrm{~h}$. Response to the cytokine was compared in culture wells that were pre-coated or not with fibronectin. Results are mean cell number per culture well ( $\mathrm{n}=6$ per mean value) and $\left[{ }^{*}\right]$ indicates significant difference at $P \leqslant 0.05$ from the corresponding control value without fibronectin. (B) TUNEL staining was performed on WEG-1 cells following exposure to $5 \mathrm{ng} / \mathrm{ml} \mathrm{TNF-} \alpha$ for $48 \mathrm{~h}$. Nuclei in which chromatin degradation has occurred due to the TNF- $\alpha$-induction of apoptosis are colored in dark brown (arrow). Counter-staining was performed with a DNA fluorochrome to count the nuclei of the viable cells (scale bar $=7 \mu \mathrm{m}$ ). Compared to control cultures, addition of TNF- $\alpha$ resulted in a 2.8 -fold increase in the percentage of TUNEL-positive WEG-1 cells. Thus the decrease in cell viability induced by TNF- $\alpha$ in (A) was correlated with an increased incidence of apoptosis in (B) 
mainly estrogen, in the ovariectomized mouse. ${ }^{148}$ After implantation, these type I TNF- $\alpha$ receptors are found to be expressed in the undecidualized area of the stroma and, to a lesser degree, in the mesometrial region of the decidua in mice. ${ }^{149}$ TNF- $\alpha$ is synthesized in the uterine epithelium as well as more diffusely in the adjacent stroma and its expression is up-regulated at both mRNA and protein levels by steroid hormones, mainly progesterone, in the ovariectomized mouse. ${ }^{150}$ Shortly after implantation, TNF- $\alpha$ mRNA and protein synthesis is abundant in the primary decidual region in both mice ${ }^{151}$ and rats. ${ }^{29}$ In the mature decidua, high TNF- $\alpha$ expression is homogenously distributed throughout both anti-mesometrial and mesometrial areas. In accordance with these observations, the uterine content in TNF- $\alpha$ mRNA and protein was found to reach a peak during the period when both the luminal epithelium and the anti-mesometrial area enter into regression. ${ }^{152}$ In addition, stimulation of a mouse pseudo-pregnant uterus with an embryo-free deciduogenic signal resulted in a transient decrease in TNF- $\alpha$ content that was interpreted as resulting from the degradation of the TNF- $\alpha$ producing epithelium layer. ${ }^{153}$ Although the impact of TNF- $\alpha$ on decidual cell death is not known, there is preliminary evidence that the cytokine induces cell death in mouse uterine epithelial cells (Figure 4).

Our knowledge of the molecular mechanisms underlying uterine cell death is still poor. In the mature decidua, cell death is apparently preceded by a change in the ratio between pro-apoptotic Bax and anti-apoptotic Bcl-2. In ovariectomized steroid-primed rats subjected to artificial decidualization, Bax mRNA and protein expression levels were found to increase in both intensity and extent as the process of decidualization spreads throughout the subepithelial stroma whereas Bcl-2 mRNA and protein expression levels decreased concomitantly. ${ }^{154}$ Declining $\mathrm{Bcl}-2$ protein synthesis is also described in the regressing decidua of pregnant rats. ${ }^{95} \mathrm{Bcl}-2$ immunostaining was undetectable in decidual cells surrounding the ectoplacental cone but persisted in the extreme end of the mesometrial area of the rat implantation chamber. Interestingly, the mesometrial region where the decidua basalis persists throughout pregnancy, remains Bax negative during that same period. ${ }^{154}$ The expression of cell death-associated genes has been also documented using rat uterine epithelial cell lines. ${ }^{134}$ In this in vitro model, serum withdrawal from the culture medium was found to induce a deleterious change in the mRNA ratio between the pro-apoptotic and anti-apoptotic isoforms of $\mathrm{Bcl}-\mathrm{X}$. No alteration was found in the expression levels of anti-apoptotic $\mathrm{Bcl}-2$ and pro-apoptotic Bax in these cell cultures. $^{134}$

\section{Conclusion}

If the consensus is well established that the survival-ordemise fate of a given cell is determined by the intra-cellular ratio between pro-apoptotic and anti-apoptotic regulators as well as by the integration of extra-cellular death-activating and death-suppressing signals, we must concede that the identity of these determinants and their mode of interaction remain disappointedly vague in the implanting embryo and the receptive uterus. For instance, answers to the questions pertaining to the mechanism underlying the tagging of redundant cells for deletion from the inner cell mass in blastocysts, the nature of the forces in action during the removal of the luminal epithelium around the implantation site or the importance of ovarian steroid hormones and their receptors during decidual regression are not available. Clearly, the interest of these questions in their own right as well as their potential relevance in the search for new approaches in the diagnostic and treatment of reproductive deficiencies make this field worthy of further studies.

\section{Acknowledgements}

The authors own research activities are financially supported by an Action de Recherche Concertée de la Direction Générale de la Recherche de la Communauté Française de Belgique (grant number 96/01-96). S Pampfer is Chercheur Qualifié and I Donnay is Collaborateur Scientifique of the Fonds National de la Recherche Scientifique de Belgique.

\section{References}

1. Clarke PG and Clarke S (1996) Nineteenth century research on naturally occurring cell death and related phenomena. Anat. Embryol. 193: 81-99

2. Sanders EJ and Wride MA (1995) Programmed cell death in development. Int. Rev. Cytol. 163: 105-173

3. Kerr JF, Wyllie A and Currie AR (1972) Apoptosis: a basic biological phenomenon with wide-ranging implications in tissue kinetics. Br. J. Cancer 26: $239-257$

4. Raff MC (1998) Cell suicide for beginners. Nature 396: 119-112

5. Jacobson MD, Weil M and Raff MC (1997) Programmed cell death in animal development. Cell 88: 347-354

6. Milligan CE and Schwartz LM (1997) Programmed cell death during animal development. Br. Med. Bul. 52: 570-590

7. Spencer SJ, Cataldo NA and Jaffe RB (1996) Apoptosis in the human female reproductive tract. Obstet. Gynecol. Surv. 51:314-323

8. Vinatier D, Dufour P and Subtil D (1996) Apoptosis: a programmed cell death involved in ovarian and uterine physiology. Eur. J. Obstet. Gynecol. Biol. Reprod. 67: 85-102

9. Gosden R and Spears N (1997) Programmed cell death in the reproductive system. Br. Med. Bull. 53: 644-661

10. Wilson IB (1963) A new factor associated with the implantation of the mouse egg. J. Reprod. Fert. 5: 281-282

11. Potts DM (1968) The ultra-structure of implantation in the mouse. J. Anat. 103: 77-90

12. Finn CA and Lawn AM (1968) Transfer of cellular material between the uterine epithelium and trophoblast during early stages of implantation. J. Reprod. Fert. 15: $333-336$

13. Smith MS and Wilson IB (1971) Histological observations on early implantation in the mouse. J. Embryol. Exp. Morph. 25: 165-174

14. El-Shershaby AM and Hinchliffe JR (1974) Cell redundancy in the zona-intact pre-implantation mouse blastocyst: a light and electron microscope study of dead cells and their fate. J. Embryol. Exp. Morph. 31: 643-654

15. Copp AJ (1978) Interaction between inner cell mass and trophectoderm of the mouse blastocyst. J. Embryol. Exp. Morph. 48: 109-125

16. Handyside $\mathrm{AH}$ and Hunter S (1986) Cell division and death in the mouse blastocyst before implantation. Roux's Arch. Dev. Biol. 195: 519-526

17. Pampfer S, De Hertogh R, Vanderheyden I, Michiels M and Vercheval M (1990) Decreased inner cell mass proportion in blastocysts from diabetic rats. Diabetes 39: $471-476$

18. Lea RG, McCracken JE, McIntyre SS, Smith W and Baird JD (1996) Disturbed development of the pre-implantation embryo in the insulin-dependent diabetic BB/E rat. Diabetes 45: $1463-1470$ 
19. Pampfer S, Vanderheyden I, McCracken JE, Vesela J and De Hertogh R (1997) Increased cell death in rat blastocysts exposed to maternal diabetes in utero and to high glucose or tumor necrosis factor- $\alpha$ in vitro. Development 124: $4827-$ 4836

20. Moley KH, Chi MM, Knudson CM, Korsmeyer SJ and Mueckler MM (1998) Hyperglycemia induces apoptosis in pre-implantation embryos through cell death effector pathways. Nature Med. 4: 1421-1424

21. De Hertogh R, Vanderheyden I, Pampfer S, Robin D and Delcourt J (1992) Maternal insulin treatment improves pre-implantation embryo development in diabetic rats. Diabetologia 35: 406-408

22. Jurisicova A, Rogers I, Fasciani A, Casper RF and Varmuza S (1998) Effect of maternal age and conditions of fertilization on programmed cell death during murine pre-implantation embryo development. Mol. Hum. Reprod. 4: 139-145

23. Brison DR and Schultz RM (1997) Apoptosis during mouse blastocyst formation: evidence for a role for survival factors including transforming growth factor- $\alpha$. Biol. Reprod. 56: 1088-1096

24. Tamada H, Das SK, Andrews GL and Dey SK (1991) Cell-type specific expression of transforming growth factor- $\alpha$ in the mouse uterus during the periimplantation period. Biol. Reprod. 45: 365-372

25. Paria BC, Das SK, Huet-Hudson YM and Dey SK (1994) Distribution of transforming growth factor- $\alpha$ precursors in the mouse uterus during the periimplantation period and after steroid hormone treatments. Biol. Reprod. 50: $481-491$

26. Rappolee DA, Brenner CA, Schultz RM, Mark D and Werb Z (1988) Developmental expression of PDGF, TGF- $\alpha$ and TGF- $\beta$ genes in preimplantation mouse embryos. Science 241: $1823-1825$

27. Dardik A, Smith RM and Schultz RM (1992) Co-localization of transforming factor- $\alpha$ and a functional epidermal growth factor receptor (EGF-R) to the inner cell mass and preferential localization of the EGF-R on the baso-lateral surface of the trophectoderm in the mouse blastocyst. Dev. Biol. 154: 396-409

28. Brison DR and Schultz RM (1998) Increased incidence of apoptosis in transforming growth factor- $\alpha$-deficient mouse blastocysts. Biol. Reprod. 59 : $136-144$

29. Yelavarthi KK, Chen HL, Yang Y, Cowley BD, Fishback JL and Hunt JS (1991) Tumor necrosis factor- $\alpha \mathrm{mRNA}$ and protein in rat uterine and placental cells. J. Immunol. 146: 3840-3848

30. Pampfer S, Vanderheyden I, Wuu YD, Baufays L, Maillet O and De Hertogh R (1995a) Possible role for TNF- $\alpha$ in early embryopathy associated with maternal diabetes in the rat. Diabetes 44: 531-536

31. Pampfer S, Vanderheyden I, Vesela J and De Hertogh R(1995b) Neutralization of tumor necrosis factor- $\alpha$ (TNF- $\alpha$ ) action on cell proliferation in rat blastocysts by antisense oligodeoxyribonucleotides directed against TNF- $\alpha$ p60 receptor. Biol. Reprod. 52: 1316-1326.

32. Wuu YD, Pampfer S, Vanderheyden I, Lee KH and De Hertogh R (1998) Impact of tumor necrosis factor- $\alpha$ on mouse embryonic stem cells. Biol. Reprod. 58 : $1416-1424$

33. Pampfer S, Wuu YD, Vanderheyden I and De Hertogh R (1994) Expression of tumor necrosis factor- $\alpha$ (TNF- $\alpha$ ) receptors and selective effect of TNF- $\alpha$ on the inner cell mass in mouse blastocysts. Endocrinology 134: 206-212

34. Wuu YD, Pampfer S, Becquet P, Vanderheyden I, Lee KH and De Hertogh R (1999) Tumor necrosis factor- $\alpha$ decreases the viability of mouse blastocysts in vitro and in vivo. Biol. Reprod. 60: 479-483

35. Weil M, Jacobson MD, Coles HS, Davies TJ, Gardner RL, Raff KD and Raff MC (1996) Constitutive expression of the machinery for programmed cell death. J. Cell. Biol. 133: 1053-1059

36. Pierce GB, Lewellyn AL and Parchment RE (1989) Mechanism of programmed cell death in the blastocyst. Proc. Natl. Acad. Sci. USA 86: 3654-3658

37. Gramzinski RA, Parchment RE and Pierce GB (1990) Evidence linking programmed cell death in the blastocyst to polyamine oxidation. Differentiation 43: $59-65$

38. Pierce GB, Parchment RE and Lewellyn AL (1991) Hydrogen peroxide as a mediator of programmed cell death in the blastocyst. Differentiation 46: 181 186

39. Coucouvanis E and Martin GR (1995) Signals for death and survival: a two-step mechanism for cavitation in the vertebrate embryo. Cell 83: 279-287

40. Martin GR, Wiley LM and Damjanov I (1977) The development of cystic embryoid bodies in vitro from clonal teratocarcinoma stem cells. Dev. Biol. 61: $230-244$
41. Poelmann RE (1980) Differential mitosis and degeneration patterns in relation to the alterations in the shape of the embryonic ectoderm of early postimplantation mouse embryos. J. Embryol. Exp. Morph. 55: 33-51

42. Manova K, Tomihara-Newberger C, Wang S, Godelman A, Kalantry S, WittyBlease K, De Leon V, Chen WS, Lacy E and Bachvarova RF (1998) Apoptosis in mouse embryos: elevated levels in pre-gastrulae and in the distal anterior region of gastrulae of normal and mutant mice. Dev. Dyn. 213: 293-308

43. Poelmann RE (1977) Morphological changes in the ectoderm of early mouse embryos related to the patterns of cell division and cell degeneration. J. Anat. 124: $238-240$

44. Lawson KA and Pedersen RA (1987) Cell fate, morphogenetic movement and population kinetics on embryonic endoderm at the time of germ layer formation in the mouse. Development 101: 627-652

45. Adams JM and Cory S (1998) The Bcl-2 protein family: arbiters of cell survival. Science 281: $1322-1326$

46. Thornberry NA and Lazebnik Y (1998) Caspases: enemies within. Science 281: 1312-1316

47. Fleming JV, Fontanier N, Harries DN and Rees WD (1997) The growth arrest genes gas5, gas6 and CHOP-10 (gadd153) are expressed in the mouse preimplantation embryo. Mol. Reprod. Dev. 48: 310-316

48. Fleming JV, Hay SM, Harries DN and Rees WD (1998) Effects of nutrient deprivation and differentiation on the expression of growth-arrest genes (gas and gadd) in F9 embryonal carcinoma cells. Biochem. J. 330: 573-579

49. Nakano T, Ishimoto Y, Kishino J, Umeda M, Inoue K, Nagata K, Ohashi K, Mizuno K and Arita H (1997) Cell adhesion to phosphatidylserine mediated by a product of growth arrest-specific gene 6. J. Biol. Chem. 272: 29411-29414

50. Fadok VA, Bratton DL, Frasch SC, Warner ML and Henson PM (1998) The role of phosphatidylserine in recognition of apoptotic cells by phagocytes. Cell. Death Differ. 5: 551-562

51. Gueth-Hallonet C, Santa-Maria A, Verroust P and Maro B (1994) gp330 is specifically expressed in outer cells during epithelial differentiation in the preimplantation mouse embryo. Development 120: 3289-3299

52. Brenner B, KoppenhoeferU, Weinstock C, Linderkamp O, Lang F and GulbinsE (1997) Fas- and ceramide-induced apoptosis is mediated by a Rac-1-regulated activation of Jun N-terminal kinase/p38 kinases and gadd153. J. Biol. Chem. 272: 22173-22181

53. Eymin B, Dubrez L, Allouche M and Solary E (1997) Increased gadd153 messenger RNA level is associated with apoptosis in human leukemic cells treated with etoposide. Cancer Res. 57: 686-695

54. Veis DJ, Sorenson CM, Shutter JR and Korsmeyer SJ (1993) Bcl-2-deficient mice demonstrate fulminant lymphoid apoptosis, polycystic kidneys and hypopigmented hair. Cell 75: 229-240

55. Nagata M, Nakauchi H, Nakayama K, Loh D and Watanabe T (1996) Apoptosis during an early stage of nephrogenesis induces renal hypoplasia in Bcl-2deficient mice. Am. J. Pathol. 148: 1601-1611

56. Michaelidis TM, Sendtner M, Cooper JD, Airaksinen MS, Holtmann B, Meyer M and Thoenen $\mathrm{H}$ (1996) Inactivation of $\mathrm{Bcl}-2$ results in progressive degeneration of motoneurons, sympathetic and sensory neurons during early post-natal development. Neuron. 17: 75-89

57. Knudson CM, Tung KS, Tourtelotte WG, Brown GA and Korsmeyer SJ (1995) Bax-deficient mice with lymphoid hyperplasia and male germ cell death. Science 270: 96-99

58. Motoyama N, Wang F, Roth KA, Sawa H, Nakayama K, Negishi I, Senju S, Zhang Q, Fujii S and Loh DY (1995) Massive cell death of immature hematopoietic cells and neurons in Bcl-X-deficient mice. Science 267: $1506-$ 1510

59. Ross AJ, Waymire KG, Moss JE, Parlow AF, Skinner MK, Russell LD and McGregor GR (1998) Testicular degeneration in BCL-W-deficient mice. Nature Genet. 18: 251-256

60. Li P, Alleen H, Banerjee S, Franklin S, Herzog L, Johnston C, McDowell J, Paskind $M$, Rodman $L$ and Salfeld $J$ et al (1995) Mice deficient in IL-1 $\beta$ converting enzyme are defective in production of mature IL-1 $\beta$ and resistant to endotoxic shock. Cell 80: 401-411

61. Kuida K, Lippke JA, Ku G, Harding MW, Livingston DJ, Su MS and Flavell RA (1995) Altered cytokine export and apoptosis in mice deficient in interleukin-1 $\beta$ converting enzyme. Science 267: 2000-2003 
62. Bergeron L, Perez Gl, McDonald G, Shi L, Sun $Y$, Jurisicova A, Varmuza S, Latham KE, Flaws JA, Salter JC, Hara H, Moskowitz MA, Li E, Greenberg A, Tilly $\mathrm{JL}$ and Yuan J (1998) Defects in regulation of apoptosis in caspase-2-deficient mice. Genes Dev. 12:1304-1314

63. Kuida K, Zheng TS, Na S, Kuan C, Yang D, Karasuyama H, Rakic P and Flavell RA (1996) Decreased apoptosis in the brain and premature lethality in CPP32deficient mice. Nature 384: 368-372

64. Varfolomeev EE, Schuchmann M, Luria V, Chiannilkulchai N, Beckmann JS, Mett IL, Rebrikov D, Brodianski VM, Kemper OC, Kollet O, Lapidot T, Soffer D, Sobe T, Avraham KB, Goncharov T, Holtmann H, Lonai P and Wallach D (1998) Targeted disruption of the mouse caspase-8 gene ablates cell death induction by the TNF receptors, Fas/Apo1 and DR3 and is lethal prenatally. Immunity 9: 267-276

65. Kuida K, Haydar TF, Kuan CY, Gu Y, Taya C, Karasuyama H, Su MS, Rakic P and Flavell RA (1998) Reduced apoptosis and cytochrome C-mediated caspase activation in mice lacking caspase-9. Cell 94: 325-337

66. Wang S, Miura M, Jung YK, Zhu H, Li E and Yuan J (1998) Murine caspase-11, an ICE-interacting protease, is essential for the activation of ICE. Cell. 92: 501 509

67. Sha WC, Liou HC, Tuomanen El and Baltimore D (1995) Targeted disruption of the 550 subunit of $\mathrm{NF}_{\kappa} \mathrm{B}$ leads to multi-focal defects in immune responses. Cell. 80: $321-330$

68. Franzoso G, Carlson L, PoljakL, Shores EW, Epstein S, Leonardi A, Grinberg A Tran T, Sharton-Kersten T, Anver M, Love P, Brown K and Siebenlist U (1998) Mice deficient in nuclear factor $(\mathrm{NF}) \kappa \mathrm{B} / \mathrm{p} 52$ present with defects in humoral responses, germinal center reactions and splenic micro-architecture. J. Exp. Med. 187: 147-159

69. Beg AA, Sha WC, Bronson RT, Ghosh S and Baltimore D (1995a) Embryonic lethality and liver degeneration in mice lacking the RelA component of $\mathrm{NF}_{\kappa} \mathrm{B}$. Nature 376: $167-170$

70. Weih F, Carrasco D, Durham SK, Barton DS, Rizzo CA, Ryseck RP, Lira SA and Bravo R (1995) Multi-organ inflammation and hematopoietic abnormalities in mice with a targeted disruption of RelB, a member of the $\mathrm{NF}_{\kappa} \mathrm{B} /$ Rel family. Cell 80: $331-340$

71. Beg AA, Sha WC, Bronson RT and Baltimore D (1995b) Constitutive NF $F_{k} B$ activation, enhanced granulopoiesis and neonatal lethality in $\mathrm{I}_{\kappa} \mathrm{B} \alpha$-deficient mice. Genes Dev. 9: 2736-2746

72. Klement JF, Rice NR, Car BD, Abbondanzo SJ, Powers GD, Bhatt PH, Chen $\mathrm{CH}$, Rosen CA and Stewart CL (1996) $\left.\right|_{\kappa} B \alpha$ deficiency results in a sustained $\mathrm{NF}_{\kappa} \mathrm{B}$ response and severe widespread dermatitis in mice. Mol. Cell Biol. 16: 2341-2349

73. Cecconi F, Alvarez-Bolado G, Meyer BI, Roth KA and Gruss P (1998) Apaf-1 (CED-4 homolog) regulates programmed cell death in mammalian development. Cell 94: 727-737

74. Yoshida H, Kong YY, Yoshida R, Elia AJ, Hakem A, Hakem R, Penninger JM and Mak TW (1998) Apaf-1 is required for mitochondrial pathways of apoptosis and brain development. Cell 94: 739-750

75. Baichwal VR and Bauerle PA (1997) Activate NF $k B$ or die. Curr. Biol. 7: 94 -96

76. Kohchi C, Tanabe Y, Noguchi K, Mizuno DI and Soma GI (1996) Induction of differentiation in embryonic stem cells by $26 \mathrm{kD}$ membrane-bound tumor necrosis factor (TNF) and 17 kD-free TNF. In Vivo 10: 19-28

77. Levine AJ (1997) p53, the cellular gatekeeper for growth and division. Cell 88: $323-331$

78. Donehower LA, Harvey M, Slagle BL, McArthur MJ, Montgomery CA, Butel JS and Bradley A (1992) Mice deficient for P53 are developmentally normal but susceptible to spontaneous tumors. Nature 356: 215-221

79. Sabapathy K, Klemm M, Jaenisch R and Wagner EF (1997) Regulation of ES cell differentiation by functional and conformational modulation of $\mathrm{p} 53$. EMBO J. 16:6217-6229

80. Norimura T, Nomoto S, Katsuki M, Gondo Y and Kondo S (1996) p53-dependent apoptosis suppresses radiation-induced teratogenesis. Nature Med. 2: $577-$ 580

81. Haines DS (1997) The MDM2 proto-oncogene. Leuk. Lymphoma. 26: 227-238

82. Jones SN, Roe AE, Donehower LA and Bradley A (1995) Rescue of embryonic lethality in MDM2-deficient mice by absence of p53. Nature 378: 206-208

83. Montes de Oca Luna R, Wagner DS and Lozano G (1995) Rescue of early embryonic lethality in MDM2-deficient mice by deletion of p53. Nature 378: 203-206
84. Stephens LE, Sutherland AE, Klimanskaya IV, Andrieux A, Meneses J, Pedersen RA and Damsky $\mathrm{CH}$ (1995) Deletion of $\beta 1$-integrins in mice results in inner cell mass failure and peri-implantation lethality. Genes Dev. 9: 18831895

85. Fassler $R$ and Meyer $M$ (1995) Consequences of lack of $\beta 1$-integrin gene expression in mice. Genes Dev. 9: 1896-1908

86. Chen WS, Manova K, Weinstein DC, Duncan SA, Plump AS, Prezioso VR, Bachvarova RF and Darnell JE (1994) Disruption of the HNF-4 gene, expressed in visceral endoderm, leads to cell death in embryonic ectoderm and impaired gastrulation of mouse embryos. Genes Dev. 8: 2466-2477

87. Zeitlin S, Liu JP, Chapman DL, Papaioannou VE and Efstratiadis A (1995) Increased apoptosis and early embryonic lethality in mice nullizygous for the Huntington's disease gene homologue. Nature Genet. 11: 155-163

88. Xanthoudakis S, Smeyne RJ, Wallace JD and Curran T (1996) The redox/DNA repair protein Ref- 1 is essential for early embryonic development in mice. Proc. Natl. Acad. Sci. USA 93: 8919-8923

89. Lim DS and Hasty P (1996) A mutation in mouse Rad51 results in an early embryonic lethal that is suppressed by a mutation in p53. Mol. Cell Biol. 16: $7133-7143$

90. Enders AC and Schlafke S (1967) A morphological analysis of the early implantation stages in the rat. Am. J. Anat. 120: 185-226

91. Potts DM (1969) The ultra-structure of egg implantation. Adv. Reprod. Physiol. 4: $241-267$

92. Lawn AM (1969) Uterine implantation of the mammalian ovum. Proc. R. Soc. Med. 62: $141-143$

93. El-Shershaby AM and Hinchliffe JR (1975) Epithelial autolysis during implantation of the mouse blastocyst: an ultra-structural study. J. Embryol. Exp. Morph. 33: 1067-1080

94. Parr EL, Tung HN and Parr MB (1987) Apoptosis as the mode of uterine epithelial cell death during embryo implantation in mice and rats. Biol. Reprod. 36: $211-225$

95. Piacentini $M$ and Autuori $F$ (1994) Immunohistochemical localization of tissue transglutaminase and $\mathrm{Bcl}-2$ in rat uterine tissues during embryo implantation and post-partum involution. Differentiation 57: 51-61

96. Smith AF and Wilson IB (1974) Cell interaction at the maternal-embryonic interface during implantation in the mouse. Cell Tissue Res. 152: 525-542

97. Tachi S, Tachi $C$ and Lindner HR (1970) Ultra-structural features of blastocyst attachment and trophoblast invasion in the rat. J. Reprod. Fert. 21: 37-56

98. Finn CA and Bredl JC (1973) Studies on the development of the implantation reaction in the mouse uterus: influence of actinomycin D. J. Reprod. Fertil. 34: 247-253

99. Welsh AO and Enders AC (1991) Chorio-allantoic placenta formation in the rat: I. Luminal epithelial cell death and extra-cellular matrix modifications in the mesometrial region of implantation chambers. Am. J. Anat. 192: 215-231

100. Welsh AO (1993a) Chorioallantoic placenta formation in the rat: III. Granulated cells invade the uterine luminal epithelium at the time of epithelial cell death. Biol. Reprod. 49: 38-57

101. Katz S and Abrahamson PA (1981) Ultra-structural observations on the involution of the anti-mesometrial decidua. Acta. Anat. 111: 72-75

102. Katz $S$ and Abrahamson PA (1987) Involution of the anti-mesometrial decidua in the mouse. Anat. Embryol. 176: 251-258

103. Bulmer $D$ and Dickson $A D$ (1961) The fibrinoid capsule of the rat placenta and the disappearance of the decidua. J. Anat. 95: 300-310

104. Welsh $A O$ and Enders AC (1985) Light and electron microscopic examination of the mature decidual cells of the rat with emphasis on the anti-mesometrial decidua and its degeneration. Am. J. Anat. 172: 1-29

105. Alexander CM, Hansell EJ, Behrendtsen O, Flannery ML, Kishnani NS, Hawkes SP and Werb Z (1996) Expression and function of matrix metalloproteinases and their inhibitors at the maternal-embryonic boundary during mouse embryo implantation. Development 122: 1723-1736

106. Krehbiel $\mathrm{RH}$ (1937) Cytological studies of the decidual reaction in the rat during early pregnancy and in the production of deciduomata. Physiol. Zool. 10:212233

107. Lundkvist $O$ and Nilsson BO (1982) Endometrial ultrastructure in the early uterine response to blastocysts and artificial deciduogenesis stimuli in rats. Cell Tissue Res. 225: 355-364 
108. Velardo JT, Dawson AB, Olsen AG and Hisaw FL (1953) Sequence of histological changes in the uterus and vagina of the rat during prolongation of pseudo-pregnancy associated with the presence of deciduomata. Am. J. Anat. 93: $273-305$

109. Craig SS and Jollie WP (1975) Epithelial ultra-structure during decidualization in rats. Anat. Embryol. 163: 215-222

110. Hinchliffe JR and El-Shershaby AM (1975) Epithelial cell death in the oilinduced decidual reaction of the pseudo-pregnant mouse: an ultra-structural study. J. Reprod. Fertil. 45: 463-468

111. Andrade CG, Abrahamson PA, GodinhoF, SamuelE and Zorn TM(1996)Death and replacement of uterine epithelial cells during oil-induced deciduoma development in the mouse. Anat. Rec. 244: 316-326

112. Gu Y, Jow GM, Moulton BC, Lee C, Sensibar JA, Park-Sarge OK, Chen TJ and Gibori G (1994) Apoptosis in decidual tissue regression and reorganization. Endocrinology 135: 1272-1279

113. Schlafke S and Enders AC (1975) Cellular basis of interaction between trophoblast and uterus at implantation. Biol. Reprod. 12: 41-65

114. Schlafke S, Welsh AO and Enders AC (1985) Penetration of the basal lamina of the uterine luminal epithelium during implantation in the rat. Anat. Rec. 212: 47 56

115. Bevilacqua EM and Abrahamson PA (1989) Trophoblast invasion during implantation of the mouse embryo. Arch. Biol. Med. Exp. 22: 107-118

116. Blankenship TN and Given R (1992) Penetration of the uterine epithelial basement membrane during blastocyst implantation in the mouse. Anat. Rec. 233: $196-204$

117. Frisch SM and Ruoslathi E (1997) Integrins and anoikis. Curr. Opin. Cell Biol. 9: 701-706

118. Sappino AP, Huarte J, Belin D and VassalliJD (1989) Plasminogen activators in tissue remodelling and invasion: mRNA localization in mouse ovaries and implanting embryos. J. Cell. Biol. 109: 2471-2479

119. Reponen P, Leivo I, Sahlberg C, Apte SS, Olsen BR, Thesleff I and Tryggvason K (1995) 92-kDa type IV collagenase and TIMP-3, but not 72 kDa type IV collagenase or TIMP-1 or TIMP-2 are highly expressed during mouse embryo implantation. Dev. Dyn. 202: 388-396

120. Harvey MB, Leco KJ, Arcellana-Panlilio MY, Zhang X, Edwards DR and Schultz GA (1995) Proteinase expression in early mouse embryos is regulated by leukemia inhibitory factor and epidermal growth factor. Development 121 : $1005-1014$

121. Zhang X, Shu MA, Harvey MB and Schultz GA (1996) Regulation of urokinase plasminogen activator production in implanting mouse embryo: effect of embryo interaction with extra-cellular matrix. Biol. Reprod. 54: 1052-1058

122. Kamijo T, Rajabi MR, Mizunuma H and lbuki Y (1998) Biochemical evidence for autocrine/paracrine regulation of apoptosis in cultured uterine epithelial cells during mouse embryo implantation in vitro. Mol. Hum. Reprod. 4: 990-998

123. Teesalu T, Blasi F and Talarico D (1996) Embryo implantation in mouse: fetomaternal coordination in the pattern of expression of UPA, UPAR, PAl-1 and a2MR/LRP genes. Mech. Dev. 56: 103-116

124. Afonso $S$, Romagnano $L$ and Babiarz $B$ (1997) The expression and function of cystatin- $C$ and cathepsin-B and cathepsin- $L$ during mouse embryo implantation and placentation. Development 124: 3415-3425

125. Brown TL, Moulton BC, Witte DP, Swertfeger DK and Harmony JA (1996) Apolipoprotein $\mathrm{J} /$ clusterin expression defines distinct stages of blastocyst implantation in the mouse uterus. Biol. Reprod. 55: 740-747

126. French LE, Chonn A, Ducrest D, Baumann B, Belin D, Wohlwend A, Kiss JZ, Sappino AP, Tschopp J and Schifferli JA (1993) Murine clusterin: molecular cloning and mRNA localization of a gene associated with epithelia differentiation processes during embryogenesis. J. Cell. Biol. 122: 1119-1130

127. Ahuja HS, Tenniswood M, Lockshin R and Zakeri ZF (1994) Expression of clusterin in cell differentiation and cell death. Biochem. Cell. Biol. 72: 523-530

128. Nose A and Takeichi M (1986) A novel cadherin cell adhesion molecule: its expression pattern associated with implantation and organogenesis. J. Cell. Biol. 103: 2649-2658

129. Kadokawa Y, Fuketa I, Nose A, Takeichi M and Nakatsji N (1989) Expression pattern of E-cadherin and $\mathrm{P}$-cadherin in mouse embryos and uteri during the peri-implantation period. Dev. Growth Differ. 31: 23-30

130. Potter SW, Gaza G and Morris JE (1996) Estradiol induces E-cadherin degradation in mouse uterine epithelium during the estrus cycle and early pregnancy. J. Cell. Physiol. 169: 1-14

131. Thompson EB (1994) Apoptosis and steroid hormones. Mol. Endocrinol. 8: $665-673$
132. Welsh AO (1993b) Uterine cell death during implantation and early placentation. Microsc. Res. Technol. 25: 223-245

133. Terada N, Yamamoto $R$, Takada T, Miyake T, Terakawa N, Wakimoto $H$, Taniguchi H, Li W, Kitamura $Y$ and Matsumoto K (1989) Inhibitory effect of progesterone on cell death of mouse uterine epithelium. J. Steroid Biochem. 33 : $1091-1096$

134. Pecci A, Scholz A, Pelster D and Beato M (1997) Progestins prevent apoptosis in a rat endometrial cell line and increase the ratio of Bcl-XI to Bcl-Xs. J. Biol. Chem. 272: $11791-11798$

135. Moulton BC and Koening BB (1983) Progestin increases cathepsin-D synthesis in uterine luminal epithelial cells. Am. J. Physiol. 244: 442-446

136. Murr SM, Stabenfeldt GH, Bradford GE and Gerschwind II (1974) Plasma progesterone during pregnancy in the mouse. Endocrinology 94: 1209-1211

137. Ogle TF, Mills TM and Soares MJ (1989) Changes in cytosolic and nuclear progesterone receptors during pregnancy in rat placenta. Biol. Reprod. 40: $1012-1019$

138. Ogle TF, Dai D, George P and Mahesh VB (1997) Stromal cell progesterone and estrogen receptors during proliferation and regression of the decidua basalis in the pregnant rat. Biol. Reprod. 57: 495-506

139. Ogle TF, Dai D, George P and Mahesh VB (1998) Regulation of the progesterone receptor and estrogen receptor in decidua basalis by progesterone and estradiol during pregnancy. Biol. Reprod. 58: 1188-1198

140. Sharkey A (1998) Cytokines and implantation. Rev. Reprod. 3: 52-61

141. Tamada H, McMaster MT, Flanders KC, Andrews GK and Dey SK (1990) Cell type-specific expression of transforming growth factor- $\beta 1$ in the mouse uterus during the peri-implantation period. Mol. Endocrinol. 4: 965-972

142. Manova K, Paynton BV and Bachvarova RF (1992) Expression of activins and TGF- $\beta 1$ and TGF- $\beta 2$ RNAs in early post-implantation mouse embryos and uterine decidua. Mech. Dev. 36: 141-152

143. Das SK, Flanders KC, Andrews GK and Dey SK (1992) Expression of transforming growth factor- $\beta$ isoforms ( $\beta 2$ and $\beta 3$ ) in the mouse uterus: analysis of the peri-implantation period and effects of ovarian steroids. Endocrinology 130: $3459-3466$

144. Lea RG, Flanders KC, Harley CB, Manuel J, Banwatt D and Clark DA (1992) Release of a transforming growth factor (TGF)- $\beta 2$-related suppressor factor from post-implantation murine decidual tissue can be correlated with the detection of a sub-population of cells containing RNA for TGF- $\beta 2$. J. Immunol. 148: $778-787$

145. Gu Y, Jayatilak PK, Parmer TG, Gauldie J, Fey GH and Gibori G (1992) «2macroglobulin expression in the mesometrial decidua and its regulation by decidual luteotropin and prolactin. Endocrinology 131: 1321-1328

146. Moulton BC (1994) Transforming growth factor- $\beta$ stimulates endometria stromal apoptosis in vitro. Endocrinology 134: 1055-1060

147. Wada K, Nomura S, Morii E, Kitamura Y, Nishizawa Y, Miyake A and Terada N (1996) Changes in levels of mRNAs of transforming growth factor(TGF)- $\beta 1,-\beta 2$, $-\beta 3$, TGF- $\beta$ type II receptor and sulfated glycoprotein- 2 during apoptosis of mouse uterine epithelium. J. Steroid Biochem. 59: 367-375

148. Roby KF, Laham N and Hunt JS (1996) Cellular localization and steroid hormone regulation of $\mathrm{mRNA}$ encoding tumor necrosis factor receptor I in mouse uterus. J. Reprod. Fert. 106: 285-290

149. Roby KF, Laham N, Kroning H, Terranova PF and Hunt JS (1995) Expression and localization of messenger RNA for tumor necrosis factor receptor (TNF-R) I and TNF-RII in pregnant mouse uterus and placenta. Endocrine 3: 557-562

150. Roby KF and Hunt JS (1994) Mouse endometrial tumor necrosis factor- $\alpha$. messenger ribonucleic acid and protein: localization and regulation by estradiol and progesterone. Endocrinology 135: 2780-2789

151. Hunt JS, Chen HL, Hu XL and Pollard JW (1993) Normal distribution of tumor necrosis factor- $\alpha$ messenger ribonucleic acid and protein in the uteri, placentas and embryos of osteopetrotic (op/op) mice lacking colony-stimulating factor-1. Biol. Reprod. 49: 441-452

152. De M, Sanford TR and Wood GW (1993) Expression of interleukin-1 interleukin- 6 and tumor necrosis factor- $\alpha$ in mouse uterus during the periimplantation period of pregnancy. J. Reprod. Fert. 97: 83-89

153. Choudhuri R and Wood GW (1993) Production of interleukin-1, interleukin-6 and tumornecrosis factor- $\alpha$ in the uterus of pseudo-pregnant mice. Biol. Reprod 49: $596-603$

154. Ackali KC, Khan SA and Moulton BC (1996) Effect of decidualization on the expression of Bax and $\mathrm{Bcl}-2$ in rat uterine endometrium. Endocrinology 137: $3123-3130$ 